DOI: 10.4274/jarem.galenos.2020.3351

J Acad Res Med 2020;10(3):252-7

\title{
Relationship Between Vitamin D, Calcium, and Phosphorus Levels
}

\author{
(1) Burcu Çaykara1, (1) Güler Öztürk1, (1) Hacer Hicran Mutlu2, (1) Ebru Arslan1 \\ ${ }^{1}$ isstanbul Medeniyet University Faculty of Medicine, Department of Physiology, İstanbul, Turkey \\ ${ }^{2}$ istanbul Medeniyet University Faculty of Medicine, Department of Family Medicine, İstanbul, Turkey
}

Cite this article as: Çaykara B, Öztürk G, Mutlu HH, Arslan E. Relationship Between Vitamin D, Calcium, and Phosphorus Levels. J Acad Res Med 2020;10(3):252-7

\begin{abstract}
Objective: Our study aimed to determine the relationship between the prevalence of vitamin D deficiency and calcium and phosphorus levels by retrospectively obtaining vitamin $\mathrm{D}$, calcium, and phosphorus values.

Methods: Vitamin D, calcium, and phosphorus levels of patients admitted to family medicine between October 2015 and December 2017 were evaluated. Shapiro-Wilk, Mann-Whitney U, and Spearman's rho tests were used for data analysis and p-values $<0.05$ were considered to be statistically significant.

Results: A total of 1,063 patients were included in the study. The percentage of patients with normal vitamin D levels was $20.5 \%$ and those with normal calcium and phosphorus levels were $97.1 \%$ and $84.9 \%$ of the study population, respectively. Positive correlation was found between vitamin D levels, calcium, and age.

Conclusion: In our study, the prevalence of vitamin D deficiency was found to be $49.6 \%$.

Keywords: Vitamin D, calcium, phosphorus
\end{abstract}

\section{INTRODUCTION}

Vitamin $D$ is synthesized in the skin by exposure to sunlight, but can also be obtained exogenously from the diet (1). Dehydrocholesterol in the skin is converted to previtamin $D$ by exposure to sunlight. Previtamin $D$ is transported to the liver where it is converted into 25 -hydroxyvitamin $\mathrm{D}[25(\mathrm{OH}) \mathrm{D}]$, which is the major circulating form. $25(\mathrm{OH}) \mathrm{D}$ is further converted in the kidney into the active form 1,25-dihydroxyvitamin $D\left[1,25(\mathrm{OH})_{2} \mathrm{D}\right]$ (2). To assess vitamin $D$ levels, measurement of serum $25(\mathrm{OH})$ D, which has a half-life of about three weeks is performed (3). Vitamin $D$, which is fat soluble, plays an important role not only in the musculoskeletal system, but also in all tissues, which have vitamin $D$ receptors (4). The main function of vitamin $D$ is to maintain calcium ( $\mathrm{C} a$ ) and phosphorus (P) balance in the body by promoting $\mathrm{Ca}$ and $\mathrm{P}$ absorption from the intestines and kidneys (5). In vitamin D deficiency, only $10 \%-15 \%$ of calcium and $50 \%-60 \%$ of phosphorus can be absorbed from ingested foods (6).

Serum 25(OH)D levels are interpreted as follows; $<10 \mathrm{ng} / \mathrm{mL}$ severe deficiency, $<20 \mathrm{ng} / \mathrm{mL}$-deficiency, $20-30 \mathrm{ng} / \mathrm{mL}$-insufficiency, $>30 \mathrm{ng} / \mathrm{mL}$-sufficient, and $>150 \mathrm{ng} / \mathrm{mL}$-intoxication $(7,8)$. It is reported that the main underlying cause of vitamin $D$ deficiency, which is now considered to be a global health issue, is insufficient

ORCID IDs of the authors: B.Ç. 0000-0001-7063-2140; G.Ö. 0000-0001-6556-3662; H.H.M. 0000-0003-3712-0068; E.A. 0000-0001-5309-3931. 
exposure to sunlight (9). Vitamin D levels can also be affected by other factors such as age, sex, ethnicity, and seasonal variations (10). Low levels of vitamin D were found to be associated with hypertension, cardiovascular diseases, chronic musculoskeletal pain, and various malignancies (4). Our study aimed to determine the relationship between vitamin $D$ deficiency and calcium and phosphorus levels.

\section{METHODS}

Vitamin D, calcium, and phosphorus levels from the hospital registries of İstanbul Medeniyet University, Göztepe Training and Research Hospital, Department of Family Medicine between October 2015 and December 2017 were retrospectively evaluated. Ethical approval was obtained from the Ethics Committee of İstanbul Medeniyet University, Göztepe Training and Research Hospital (approval number: 2018/0336, date: 12.09.2018). Since our study was retrospective, consent forms were not obtained from patients. All subjects who had been tested concurrently for vitamin D, calcium, and phosphorus levels were included in the study. In cases where there was more than one measurement of the subjects under follow-up, the date of the first measurement was taken into consideration, and other measurements of the same subject were not included in the study.

\section{Statistical Analysis}

SPSS 22 (IBM Corp.; Armonk, NY, USA) were used for statistical analysis. Data analyses were performed with Shapiro-Wilk, Mann-
Whitney $U$ and Spearman's rho tests. P-value $<0.05$ was considered to be statistically significant.

\section{RESULTS}

The number of subjects who had undergone concurrent measurements of vitamin D, calcium, and phosphorus levels between October 2015 and December 2017 was determined to be 1,063, of which 298 were male and 765 were female. The mean age of the subjects admitted to the department of family medicine was $50.48 \pm 17.51$, the mean vitamin D value was $22.24 \pm 14.85$, the mean calcium value was $9.45 \pm 0.46$, and the mean phosphorus value was $3.64 \pm 0.56$. When these values were compared between men and women, it was determined that only phosphorus values in women were statistically significantly higher than men (Table 1). The vitamin $D$ levels of the 1,063 subjects were as follows: 198 (18.6\%) were at or below $10 \mathrm{ng} / \mathrm{mL}, 329$ (31\%) were between 10 $\mathrm{ng} / \mathrm{mL}$ and $20 \mathrm{ng} / \mathrm{mL}, 317$ (29.8\%) were between $20 \mathrm{ng} / \mathrm{mL}$ and $30 \mathrm{ng} / \mathrm{mL}, 218$ (20.5\%) were between $30 \mathrm{ng} / \mathrm{mL}$ and $150 \mathrm{ng} / \mathrm{mL}$, and only one subject had a vitamin D level (0.1\%) above $150 \mathrm{ng} /$ $\mathrm{mL}$ (Table 2). Vitamin $\mathrm{D}$ levels were similar between women and men. When grouped according to vitamin $D$ levels, a statistically significant difference was found between men and women only at levels of $30 \mathrm{ng} / \mathrm{mL}$ and $150 \mathrm{ng} / \mathrm{mL}$ ( $p=0.019$ ) (Table 3). Based on calcium levels, subjects were divided into hypocalcemia, normal, and hypercalcemia groups; 13 (1.2\%) subjects had hypocalcemia, $18(1.7 \%)$ subjects had hypercalcemia, and 1,032 (97.1\%) subjects

\section{Table 1. The mean values of patient data}

\begin{tabular}{|c|c|c|c|c|c|c|c|c|c|c|c|}
\hline Category & Number & Minimum & \multicolumn{3}{|l|}{ Maximum } & \multicolumn{3}{|l|}{ Mean } & \multicolumn{3}{|l|}{ SD } \\
\hline Age (year) & 1,063 & 3 & \multicolumn{3}{|l|}{94} & \multicolumn{3}{|l|}{50.48} & \multicolumn{3}{|l|}{17.51} \\
\hline Vitamin D (ng/mL) & 1,063 & 2.6 & \multicolumn{3}{|l|}{150.8} & \multicolumn{3}{|l|}{22.24} & \multicolumn{3}{|l|}{14.85} \\
\hline Phosphorus (mg/dL) & 1,063 & 1.80 & \multicolumn{3}{|l|}{6.8} & \multicolumn{3}{|l|}{3.64} & \multicolumn{3}{|l|}{0.56} \\
\hline \multicolumn{6}{|l|}{ Men } & \multicolumn{6}{|l|}{ Women } \\
\hline Age (year) & 298 & 3 & 93 & 51.57 & 18.69 & 765 & 4 & 94 & 50.05 & 17.02 & 0.109 \\
\hline Vitamin D (ng/mL) & 298 & 5.1 & 89.2 & 22.22 & 11.54 & 765 & 2.6 & 150.8 & 22.25 & 15.96 & 0.086 \\
\hline Calcium (mg/dL) & 298 & 7.2 & 11.1 & 9.48 & 0.43 & 765 & 5.9 & 11.7 & 9.44 & 0.47 & 0.239 \\
\hline Phosphorus (mg/dL) & 298 & 2 & 6.1 & 3.49 & 0.59 & 765 & 1.8 & 6.8 & 3.7 & 0.54 & $<0.001$ \\
\hline
\end{tabular}

\section{Table 2. Serum $25(\mathrm{OH}) \mathrm{D}$ values}

\begin{tabular}{|c|c|c|c|c|}
\hline \multirow{3}{*}{$n=1,063$} & Minimum & Maximum & Mean & SD \\
\hline & 2.6 & 150.8 & 22.24 & 14.85 \\
\hline & $\mathrm{n}$ & & $\%$ & \\
\hline$<10 \mathrm{ng} / \mathrm{mL}$ & 198 & & 18.6 & \\
\hline $10-20 \mathrm{ng} / \mathrm{mL}$ & 329 & & 31 & \\
\hline $20-30 \mathrm{ng} / \mathrm{mL}$ & 317 & & 29.8 & \\
\hline $30-150 \mathrm{ng} / \mathrm{mL}$ & 218 & & 20.5 & \\
\hline$>150 \mathrm{ng} / \mathrm{mL}$ & 1 & & 0.1 & \\
\hline
\end{tabular}


had normal calcium levels (Table 4). When calcium levels were compared based on gender, no significant difference was observed between men and women (Table 5). Based on phosphorus levels, subjects were divided into hypophosphatemia, normal, and hyperphosphatemia groups; 98 (9.2\%) subjects had hypophosphatemia, 63 (5.9\%) subjects had hyperphosphatemia, and 902 (84.9\%) subjects had normal phosphorus levels (Table 6).
When phosphorus levels were compared based on gender, phosphorus levels were found to be significantly higher in women compared to men. Furthermore, a significantly higher number of women (87.2\%) were in the normal phosphorus level group (3-4.5 $\mathrm{mg} / \mathrm{dL}$ ) compared to men (78.9\%) ( $p<0.001)$ (Table 7). Spearman's rho test showed that vitamin $\mathrm{D}$ levels were positively correlated with calcium and age $(p<0.001)$ (Table 8).

\section{Table 3. Serum 25(OH)D values to gender}

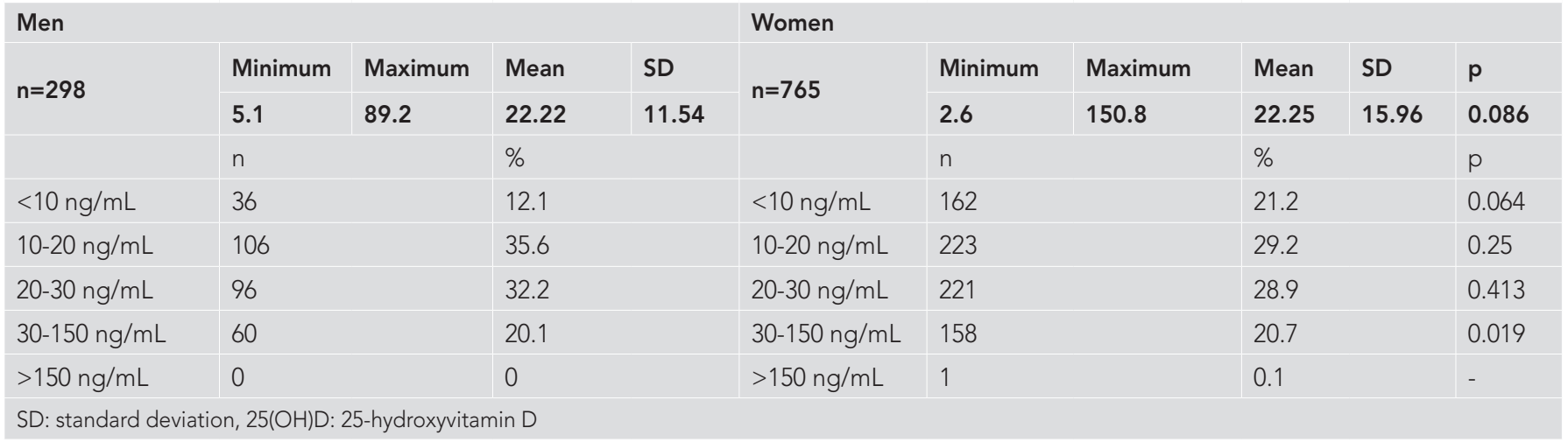

\section{Table 4. Calcium values}

\begin{tabular}{|c|c|c|c|c|}
\hline \multirow{3}{*}{$n=1,063$} & Minimum & Maximum & Mean & SD \\
\hline & 5.9 & 11.7 & 9.45 & 0.46 \\
\hline & \multicolumn{2}{|l|}{$\mathrm{n}$} & \multicolumn{2}{|l|}{$\%$} \\
\hline Hypocalcemia $<8.5$ mg/dL & \multicolumn{2}{|l|}{13} & \multicolumn{2}{|l|}{1.2} \\
\hline Normal 8.5-10.5 mg/dL & \multicolumn{2}{|l|}{1032} & \multicolumn{2}{|l|}{97.1} \\
\hline Hypercalcemia $>10.5$ mg/dL & \multicolumn{2}{|l|}{18} & \multicolumn{2}{|l|}{1.7} \\
\hline SD: standard deviation & & & & \\
\hline
\end{tabular}

\section{Table 5. Calcium values to gender}

Men

$n=298$

$<8.5 \mathrm{mg} / \mathrm{dL}$

$8.5-10.5 \mathrm{mg} / \mathrm{dL}$

$>10.5 \mathrm{mg} / \mathrm{dL}$

SD: standard deviation

\section{Women}

Mean

$9.48 \quad 0.43$

$n=765$

5.90

$\%$

0.3

98

1.7
0.43

n

$<8.5 \mathrm{mg} / \mathrm{dL} \quad 12$

$8.5-10.5 \mathrm{mg} / \mathrm{dL} \quad 740$

$>10.5 \mathrm{mg} / \mathrm{dL} \quad 13$

\begin{tabular}{|c|c|c|c|}
\hline Maximum & Mean & SD & $p$ \\
\hline \multirow[t]{5}{*}{11.7} & 9.44 & 0.47 & 0.239 \\
\hline & $\%$ & & $p$ \\
\hline & 1.6 & & 0.276 \\
\hline & 96.7 & & 0.36 \\
\hline & 1.7 & & 0.424 \\
\hline
\end{tabular}

\section{Table 6. Phosphorus values}

\begin{tabular}{|c|c|c|c|c|}
\hline \multirow{3}{*}{$n=1,063$} & Minimum & Maximum & Mean & SD \\
\hline & 1.8 & 6.8 & 3.64 & 0.56 \\
\hline & \multicolumn{2}{|l|}{$\mathrm{n}$} & \multicolumn{2}{|l|}{$\%$} \\
\hline Hypophosphatemia $<3$ mg/dL & \multicolumn{2}{|l|}{98} & \multicolumn{2}{|l|}{9.2} \\
\hline Normal 3-4.5 mg/dL & \multicolumn{2}{|l|}{902} & \multicolumn{2}{|l|}{84.9} \\
\hline Hyperphosphatemia $>4.5 \mathrm{mg} / \mathrm{dL}$ & \multicolumn{2}{|l|}{63} & \multicolumn{2}{|l|}{5.9} \\
\hline
\end{tabular}


Table 7. Phosphorus values to gender

\begin{tabular}{|c|c|c|c|c|c|c|c|c|c|c|}
\hline \multicolumn{5}{|l|}{ Men } & \multicolumn{6}{|l|}{ Women } \\
\hline \multirow{2}{*}{$n=298$} & Minimum & Maximum & Mean & SD & \multirow{2}{*}{$n=765$} & Minimum & Maximum & Mean & SD & $p$ \\
\hline & 2 & 6.1 & 3.49 & 0.59 & & 1.8 & 6.8 & 3.7 & 0.54 & $<0.001$ \\
\hline$<3 \mathrm{mg} / \mathrm{dL}$ & \multicolumn{2}{|l|}{49} & \multicolumn{2}{|l|}{16.4} & $<3 \mathrm{mg} / \mathrm{dL}$ & \multicolumn{2}{|l|}{49} & \multicolumn{2}{|l|}{6.4} & 0.813 \\
\hline $3-4.5 \mathrm{mg} / \mathrm{dL}$ & \multicolumn{2}{|l|}{235} & \multicolumn{2}{|l|}{78.9} & $3-4.5 \mathrm{mg} / \mathrm{dL}$ & \multicolumn{2}{|l|}{667} & \multicolumn{2}{|l|}{87.2} & $<0.001$ \\
\hline
\end{tabular}

Table 8. The correlation analysis for vitamin D, phosphorus, calcium, age, and gender

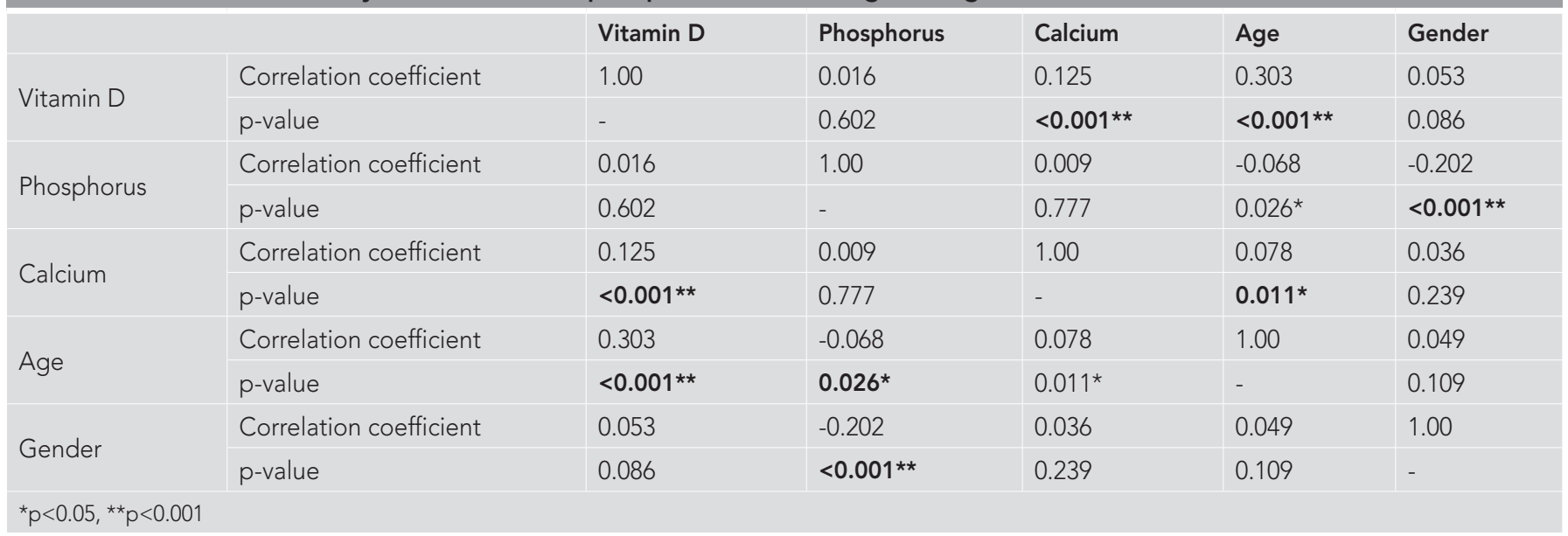

\section{DISCUSSION}

The present study shows that the prevalence of vitamin $D$ deficiency and insufficiency were $49.6 \%$ and $29.8 \%$, respectively, in our study population. The proportions of subjects with normal calcium and phosphorus levels were $97.1 \%$ and $84.9 \%$, respectively. Furthermore, vitamin $D$ levels were found to positively correlate with calcium and age $(p<0.001)$.

Vitamin D plays an important role in cellular growth and proliferation, homeostasis, oxidative stress and cellular transport (11). Vitamin D enhances calcium absorption in the intestine to maintain adequate serum calcium concentrations and is essential for bone growth and remodeling by osteoblasts and osteoclasts. A meta-analysis study found that synergistic administration of calcium and vitamin D could reduce general bone fractures by $15 \%$ and hip fractures by $30 \%$ (12). A study conducted in Spain reported that daily dietary intake of calcium and vitamin $D$ alone was not sufficient to maintain adequate serum levels (13). Factors such as decreased vitamin D absorption, low vitamin D intake and little or no sun exposure, obesity, and darker skin pigmentation may increase risk of vitamin $D$ deficiency, which is currently considered to be a global pandemic $(14,15)$.

The prevalence of vitamin D deficiency was found to be $75.2 \%$ in northwestern China, and the predictors of vitamin $D$ deficiency included dyslipidemia, coronary heart disease, obesity, smoking, age, and sex (16). Another study in the United Kingdom showed that $61.5 \%$ of the study population was vitamin D deficient, and low socio-economic status, high body mass index, and cold season were associated with low vitamin $D$ levels (17). The prevalence of vitamin D deficiency was found to be $87.1 \%$ in urban residents in Beijing and highly prevalent during the winter and spring seasons (18). Although one study found that vitamin D inadequacy and deficiency increased the odds of diabetes two-fold (19), another study conducted in Turkey found no difference between type 1 diabetics and healthy controls (20).

Yu et al. (21) found that 5.9\%,50\%, and $38.7 \%$ of the study population were severely vitamin $D$ deficient $(<10 \mathrm{ng} / \mathrm{mL})$, vitamin $D$ deficient (10-20 ng/mL), and vitamin D insufficient (20-30 ng/ $\mathrm{mL}$ ), respectively. Only $5.4 \%$ of the participants were vitamin $D$ sufficient (>30 ng/mL) and vitamin D deficiency was found to be higher in women (66.3\%) compared to men $(45.3 \%, p<0.01)(21)$. In our study, we found vitamin D levels of 198 subjects (18.6\%) to be below $10 \mathrm{ng} / \mathrm{mL}, 329$ subjects (31\%) to be between 10-20 ng/ $\mathrm{mL}, 317$ subjects (29.8\%) to be between $20-30 \mathrm{ng} / \mathrm{mL}, 218$ subjects (20.5\%) to be between $30-150 \mathrm{ng} / \mathrm{mL}$, and only one subject (0.1\%) had a vitamin D level $\geq 150 \mathrm{ng} / \mathrm{mL}$.

In a study conducted in Saudi Arabia, vitamin D deficiency and insufficiency were found in 50\% and $43.8 \%$, respectively, among 160 pregnant women (22). Vitamin D deficiency was found in 
about $44.6 \%$ of pregnant Turkish women in İmir, which is a city in the Aegean region of Turkey (23). Another study found that $97.8 \%$ of pregnant women belonging to low socio-economic status were vitamin $\mathrm{D}$ deficient. 25(OH)D levels of maternal serum and cord blood were found to positively correlate. The findings of that study suggested that vitamin $D$ stores of the mother directly affect neonatal vitamin D status (24). Öztürk et al. (25) found that $94.92 \%$ of participants had serum vitamin D levels $<30 \mathrm{ng} / \mathrm{mL}$ and $75.54 \%$ of the participants were vitamin D deficient in Gaziantep, another city located in the southeastern province of Turkey. When vitamin $D$ levels were compared between men and women, no significant difference was found in our study. We found that $79.4 \%$ of our study population had serum vitamin D levels below $30 \mathrm{ng} / \mathrm{mL}$. Similarly, a study conducted in Oman found that $79 \%$ of the study population had vitamin D levels below $30 \mathrm{ng} / \mathrm{mL}$ and the study population had normal serum calcium and alkaline phosphatase levels (26). Furthermore, $80.3 \%$ of the study population were found to have levels $<30 \mathrm{ng} / \mathrm{mL}$ in a study conducted in northern France, and $25(\mathrm{OH}) \mathrm{D}$ levels were found to correlate positively with $1,25(\mathrm{OH})_{2} \mathrm{D}$ and negatively with parathyroid hormone, but did not correlate with serum calcium or phosphate levels (27). We observed that $97.1 \%$ and $84.9 \%$ of our study population had normal calcium and normal phosphorus levels, respectively. When phosphorus levels were compared based on gender, it was found to be significantly higher in women compared to men. Furthermore, a significantly higher proportion of women (87.2\%) were in the normal phosphorus $(3-4.5 \mathrm{mg} / \mathrm{dL}$ ) level group $(p<0.001)$ compared to men (78.9\%). We found that vitamin $D$ levels were positively correlated with calcium and age but not with phosphorus levels.

Vitamin D deficiency was found in $73.9 \%$ of Turkish patients suffering from widespread musculoskeletal pain, and factors associated with hypovitaminosis included sex, age, and season (especially March) (28). A total of $75.2 \%$ of female and $33.7 \%$ male medical faculty students had vitamin D levels $<20 \mathrm{ng} / \mathrm{ml}$ in Malatya (29). In our previous study, it was reported that $75 \%$ of the participants had levels $<20 \mathrm{ng} / \mathrm{mL}, 16.1 \%$ had levels between 20-30 ng/mL, and $8.9 \%$ had levels $\geq 30 \mathrm{ng} / \mathrm{mL}$ (30). In the current study, we found sufficient vitamin D levels ( $\geq 30 \mathrm{ng} / \mathrm{mL}$ ) in $20.5 \%$ of the study population (different study population and different timeline). Although our current as well as previous studies included subjects living in the Marmara region, the differing results may be due to the regular follow-up of the current subject group in a single department and more conscious practices to prevent vitamin $\mathrm{D}$ deficiency.

\section{Study Limitations}

The limitations of our study include not knowing the underlying disease condition of the subjects, absence of age restriction while selecting the participants, addition of triple test (vitamin D, calcium, phosphorus) for the first time, not including subjects who had these same tests before October 2015, and including only subjects who applied to the department.

\section{CONCLUSION}

Our study showed that prevalence of vitamin D deficiency is high in the Turkish population despite Turkey being a sunny country and presence of awareness about vitamin D deficiency among the population. Our study population generally had normal calcium and phosphorus levels.

Ethics Committee Approval: Ethical approval was obtained from the Ethics Committee of İstanbul Medeniyet University, Göztepe Training and Research Hospital (approval number: 2018/0336, date: 12.09.2018).

Informed Consent: Since our study was retrospective, consent forms were not obtained from patients.

Peer-review: Externally peer-reviewed.

Author Contributions: Concept - B.Ç., G.Ö., H.H.M., E.A.; Design - B.Ç., G.Ö., H.H.M., E.A.; Data Collection and/or Processing - B.Ç., G.Ö., H.H.M., E.A.; Analysis and/or Interpretation - B.Ç., G.Ö., H.H.M., E.A.; Literature Search - B.Ç., G.Ö., H.H.M., E.A.; Writing Manuscript - B.Ç., G.Ö., H.H.M., E.A.

Conflict of Interest: The authors have no conflict of interest to declare.

Financial Disclosure: The authors declared that this study has received no financial support.

\section{REFERENCES}

1. Öksüz A, Kutlu R. Evaluation of the vitamin D levels of the patients who applied to Meram Medical Faculty Family Medicine Outpatient Clinic. Konuralp Tıp Derg 2018; 10: 160-4.

2. Erbay E, Mersin S, Ibrahimoğlu Ö. Effect of vitamin D on body systems. Health Care Acad J 2019; 6: 201-2016. (nette bulamadım)

3. Christakos S, Dhawan P, Verstuyf A, Verlinden L, Carmeliet G. Vitamin D: metabolism, molecular mechanism of action, and pleiotropic effects. Physiol Rev 2016; 96: 365-408.

4. Gökçen N, Coşkun Benlidayı I, Kocaer A, Başaran S. Association between vitamin $\mathrm{D}$ level and total comorbidity status in geriatric patients. Turk $\mathrm{J}$ Geriatr 2018; 21: 536-43. (nette bulamadım)

5. Yazar A, Şamlıoğlu F, Akın F, Arslan S.. The relationship of calcium elevation with vitamin D in infants. Sakarya Tıp Derg 2018; 8: 813-9. (nette bulamadım)

6. Torun T, Çavuşoğlu H. Vitamin D deficiency rickets and nursing care. J Hacettepe Univ Fac Nurs 2018; 5: 169-76.

7. Fidan F, Alkan BM, Tosun A. Çağın pandemisi: D vitamini eksikliği ve yetersizliği. Türk Osteoporoz Derg 2014; 20: 71-4.

8. Türk Endokrinoloji ve Metabolik Hastalıklar Derneği. Osteoporoz ve metabolik kemik hastaliklari tani ve tedavi kilavuzu. http:// temd.org.tr/admin/uploads/tbl_kilavuz/20180516162801-2018-0516tblkilavuz162800.pdf (link açılmıyor)

9. Holick MF. The vitamin D deficiency pandemic: Approaches for diagnosis, treatment and prevention. Rev Endocr Metab Disord 2017; 18: 153-65.

10. Cashman KD, Dowling KG, Škrabáková Z, Gonzalez-Gross M, Valtueña J, De Henauw S, et al. Vitamin D deficiency in Europe: pandemic? Am J Clin Nutr 2016; 103:1033-44.

11. Mozos I, Marginean O. Links between Vitamin D deficiency and cardiovascular diseases. Biomed Res Int 2015;2015:109275.

12. Weaver CM, Alexander DD, Boushey CJ, Dawson-Hughes B, Lappe JM, LeBoff MS, et al. Calcium plus vitamin D supplementation and risk of fractures: an updated meta-analysis from the National Osteoporosis Foundation. Osteoporos Int 2016; 27: 367-76.

13. Olza J, Aranceta-Bartrina J, González-Gross M, Ortega RM, Serra-Majem L, Varela-Moreiras G, et al. Reported dietary intake, disparity between the reported consumption and the level needed for adequacy and food sources of calcium, phosphorus, magnesium and vitamin D in the Spanish population: findings from the ANIBES Study. Nutrients 2017; 9: E168.

14. Ticinesi A, Nouvenne A, Ferraro PM, Folesani G, Lauretani F, Allegri F, et al. Idiopathic calcium nephrolithiasis and hypovitaminosis D: A casecontrol study. Urology 2016; 87: 40-5. 
15. LeFevre ML, U.S. Preventive Services Task Force. Screening for vitamin D deficiency in adults: U.S. Preventive Services Task Force recommendation statement. Ann Intern Med 2015; 162: 133-40.

16. Zhen D, Liu L, Guan C, Zhao N, Tang X. High prevalence of vitamin D deficiency among middle-aged and elderly individuals in northwestern China: its relationship to osteoporosis and lifestyle factors. Bone 2015; 71: 1-6.

17. Jolliffe DA, James WY, Hooper RL, Barnes NC, Greiller CL, Islam K, et al. Prevalence, determinants and clinical correlates of vitamin $D$ deficiency in patients with Chronic Obstructive Pulmonary Disease in London, UK. J Steroid Biochem Mol Biol 2018; 175: 138-45.

18. Ning Z, Song S, Miao L, Zhang P, Wang X, Liu J, et al. High prevalence of vitamin $D$ deficiency in urban health checkup population. Clin Nutr 2016; 35: 859-63.

19. Zhang FF, Al Hooti S, Al Zenki S, Alomirah H, Jamil KM, Rao A, et al. Vitamin $D$ deficiency is associated with high prevalence of diabetes in Kuwaiti adults: results from a national survey. BMC Public Health 2016; 16: 100. doi: 10.1186/s12889-016-2758-x.

20. Dogan B, Oner C, Feyizoglu G, Yoruk N, Oguz A. Vitamin D status of Turkish type 1 diabetic patients. Diabetes Metab Syndr 2019; 13: 2037-9.

21. Yu S, Fang H, Han J, Cheng X, Xia L, Li S, et al. The high prevalence of hypovitaminosis $D$ in China: a multicenter vitamin $D$ status survey. Medicine (Baltimore) 2015; 94: e585.

22. Al-Faris NA. High prevalence of vitamin D deficiency among pregnant Saudi women. Nutrients 2016; 8: 77.
23. Aydogmus S, Kelekci S, Aydogmus H, Eriş S, Desdicioğlu R, Yilmaz B, et al. High prevalence of vitamin $D$ deficiency among pregnant women in a Turkish population and impact on perinatal outcomes. J Matern Fetal Neonatal Med 2015; 28: 1828-32.

24. Parlak M, Kalay S, Kalay Z, Kirecci A, Guney O, Koklu E. Severe vitamin $D$ deficiency among pregnant women and their newborns in Turkey. $J$ Matern Fetal Neonatal Med 2015; 28: 548-51.

25. Öztürk ZA, Gol M, Türkbeyler iH. Prevalence of vitamin $D$ deficiency in otherwise healthy individuals between the ages of 18 and 90 years in southeast Turkey. Wien Klin Wochenschr 2017; 129: 854-55.

26. Segana HAC, Nair R, Shah FA. Vitamin D Deficiency in South Sharqiya in Oman and its Impact on ENT Patients - A Retrospective Study. Bengal Journal of Otolaryngology and Head Neck Surg 2016; 24: 122-8.

27. Souberbielle JC, Massart C, Brailly-Tabard S, Cavalier E, Chanson P. Prevalence and determinants of vitamin $D$ deficiency in healthy French adults: the VARIETE study. Endocrine. 2016; 53: 543-50.

28. Çidem M, Karacan I, Beytemur O, Kara S. Prevalence and risk factors for vitamin $\mathrm{D}$ deficiency in patients with widespread musculoskeletal pain. Turk J Med Sci 2017; 47: 728-31.

29. Sevimli R, Yakinci C, Encan M, Polat H, Sakci M, Sagir A, et al. The prevalence of vitamin $D$ deficiency-insufficiency in medical faculty students. J Turgut Ozal Med Cent 2018; 25: 125-9.

30. Sezgin G, Ozturk G, Turkal R, Caykara B. Vitamin D levels of Outpatients Admitted to a University Hospital in the Marmara Region of Turkey Over 3 years. J Med Biochem 2019; 38: 181-7. 